\title{
INSIGHT INTO THE CITY/TOWN NAMES OF LATVIA
}

\author{
Laimude Balode \\ University of Helsinki, University of Latvia
}

\begin{abstract}
Abstact. The origin of place names is a research topic for linguists (or onomasticians) and geographers, but since ancient times a wide range of people have also been interested in the subject. As Latvia is the closest neighbour to both Lithuania and Estonia, they share, to a large extent, a common history, as well as - because of this fact - a number of borrowed common words and names. This article is based on the toponymical material included in the short dictionary of Latvian geographical names entitled "No Abavas līdz Zilupei" ("From Abava to Zilupe. The origin of Latvian geographical names”), which was compiled by Laimute Balode and Ojārs Bušs and published in Rīga in 2015. It offers insights into the contemporary situation of Latvian oikonyms as well as providing comparisons of the names of inhabited places with their historical names.
\end{abstract}

Keywords: onomastics, place names, Latvia

DOI: https://doi.org/10.12697/jeful.2017.8.1.03

\section{Introduction}

Today, Latvia has 9 cities and 67 towns $(\mathrm{N}=76)$ with town privileges. Naturally there are ancient cities, such as Riga; founded in 1201, it has had town privileges since 1225. Other examples include Valmiera and Cèsis, which were granted town privileges in 1323, and Aizpute, Kuldīga, Ventspils, which were granted town status in 1378. In addition, Ludza was recorded in historical annals as early as in 1173, but town privileges were not granted until 1777 . Then we must also consider the newest towns of Latvia: Jürmala has been recognised as a town since 1956 and several inhabited places - Aknīste, Cesvaine, Ķegums, Pāvilosta, Saulkrasti, Seda, Stende, and Vangaži - were adjudged as towns in the first years of the second independence - from 1991. Others include Brocēni, Ikšksile, and Lielvārde, from 1992; Salaspils from 1993; the youngest Latvian town at the moment is Skrunda, which obtained town privileges in 1996, although its name as an inhabited place has been found in documents dating back to 1253 . It is customary 
for many countries to adopt formal criteria such as population and population density to determine settlements that have attained city status. However, the Latvian list of cities has been formed historically over the centuries and is not based on formal criteria. Three settlements of fewer than 1,000 inhabitants have town rights - Ainaži, Durbe and Subate (data from PMLP 2016). It is also important to note that Latvia has a number of villages that have populations significantly higher than those of smaller towns, but the villages have nonetheless not attained city status.

Analysing the name of a city or town is not an easy task even for experienced onomasticians, not only because many inhabited places have changed their names several times over the centuries. For instance, the contemporary city in Latgale (see map No 1) Daugavpils (see map No 2), which was recorded in 1275 as Dünaburg (1275-1656), was granted town privileges in 1582. It was briefly also called Borisoglebsk (Борисоглебск) (1656-1667 during the Russo-Swedish War): this was when the Russians captured Daugavpils on the day of St Boris and St Gleb, and this was the motivation for renaming it. Later Borisoglebsk was again renamed Dünaburg (1667-1893); as part of the Russian Empire, this city was called Dvinsk (Двинск) (1893-1920). It was not until the first independence of Latvia (particularly from 1920 until the present) that it was renamed as Daugavpils. The last name of the city undoubtedly originated from the river name Daugava (on its etymology see Balode and Bušs 2015: 88-91) + the Latvian appellative pils 'castle', evidently by translating the German toponym (Balode and Bušs 2015: 92-93).

\section{Etymology of the oikonyms}

Concerning the origin or etymology of the names of the towns of Latvia, there are few - at least at first sight - transparent toponyms, such as Baloži $<$ Latv. balodis 'pigeon', Jürmala $<$ jūra 'sea' + mala 'edge, brim, border', Saulkrasti < saule 'sun' + krasts 'coast, shore', Olaine < olis 'pebble', Plavinas < diminutive form from the Latv. appellative plava 'meadow', and others. It seems that new town names are more transparent, but perhaps this is only illusory. These abovementioned names as oikonyms $=$ inhabited place names, (or sometimes as hydronyms - cf. the river name Olaine) are rather ancient toponyms. A substantial number of names have remained unclear until recently, or there are several hypotheses regarding their origin. An example is the 
etymology of towns such as Jelgava, Kuldīga, Lielvārde, as one can mention at least three to four possible etymological explanations (see Balode and Bušs 2015, 117-120, 133-134, 141-143). The same can be claimed for the largest city of Latvia - Riga in diverse written sources to the Latin rigata 'spattered', the Baltic German Riege, the Russian puza, the Livonian rij 'threshing barn', and the German dialectal nomenclature word riege 'old riverbed brook, inlet'. Riga is also associated with the Middle Low German appellative with the meaning of 'brook, ditch with water', as well as the personal name Riga. One must also mention the remark made by Jānis Endzelīns in the manuscript of "Latvijas vietvārdu vārdnīca" ("The Dictionary of Latvian Place Names", see also LVV 2013: 286), that the origin of Riga may be related to the names of the Estonian villages of Riigi and Rüüga, even though this claim has been denied by the Estonian linguists Paul Ariste and Madis Norvik (Dambe 1990: 19). At the same time, the search for the Livonian roots of the name are based on historical facts. At present, the city name Rigga is assumed to be of Baltic origin. One of the most serious arguments here is that in German documents of the thirteenth century, the words de stat to Riga, 'the city at Riga', can be found, and these can be explained as 'the city at the River Riga'. Therefore, linking the origin of the name of the city to the name of the River Riggas upe or later Rìdzene, which was filled in the eighteenth century $<$ Baltic root ring- 'to wind, to bend, to flow zigzag'; this root can be found in rather many hydronyms in Lithuania (the rivers Ringa, Ringè) and Latvia (Lake Ringis). Moreover, there is also the Latvian appellative rïdzina 'small brook' (ME III 536), which has an etymological root that is related to the previously mentioned root ring-and is homonymic to the German Ring 'a circle, ring, curve, finger ring', but this German word is of a different origin. It is likely that the name of the city (the river or the place around the river) was given by the Curonians rather than the Germans. (Konv. XVIII 35729, Dambe 1980: 8, Dambe 1990: 5-20, Balode and Hirša 2009: 279-280, LVV 2013: 283-286, Balode and Bušs 2015: 190-193).

\section{2a. Oikonyms of Baltic origin}

Most of the oikonyms - town/city names - under review are of Baltic or Latvian origin (Baldone, Dobele, Nica, Pļavinas, Saldus, etc.). The following are some examples of the names of Baltic/Latvian origin: 
Akniste (see map No 3) - a town in the south-east of Latvia, in Sēlija, on the banks of the River Dienvidsusēja; has had town privileges since 1991. It was first mentioned in historical sources in 1298. Kazimieras Būga (Būga RR III 578-579) considers this place name to be a transferred toponym that was brought by the Selonians in the early medieval times from the contemporary territory of Lithuania to the banks of the River Aknīste (Lith. Aknysta). Jānis Endzelīns (Lvv I 13, 17-18) hypothetically compares the origin of this name to the Latvian appellative $a k a$ 'well', although he does not provide any hypotheses for the derivation type of the toponym. Explaining the origins of the name of the Lithuanian river, Aknysta, and other similar Lithuanian hydronyms, Aleksandras Vanagas (LHEŽ 37) also quotes Endzelīns and supplements his hypothesis by arguing that the Latvian word aka can be further compared to the Latvian acs 'eye' and the Lithuanian akis 'eye; ice hole; pool in a marsh', 'water basin in a marsh or almost completely overgrown lake'. (Balode and Bušs 2015: 47-48).

This was the name from the southern part of Latvia - from the border with Lithuania. The following example is from the northern part of Latvia - a town located not far from the Estonian border (see map No 4):

Alüksne (local pronunciation Oluksne) - a town in the north-east of Vidzeme on the southern bank of Lake Alüksnes ezers. The German name for this inhabited place, Marienburg, was recorded in historical documents in 1284 after the castle of St Maria on the island of the lake. Alūksne has had town privileges since 1920. The name of this town was apparently derived from the name of the River Alüksne, or possibly through the name of Lake Aluksnes ezers, with origins that are rooted in the Latvian dialectal lexeme aluogs or aluots 'spring, source' and aluksna 'swampy place'. August Bielenstein (Biel. Gr. 98) included the form that had been recorded in the thirteenth century, Alükste, which is supported by the corresponding Old Russian names of Aлblcms and Oльста that were mentioned in the Chronicle of Pskov. These Old Russian names indicate that the older name of Alüksne was Alükste (Bielenstein mentions it as a parallel name that continued to be used in the nineteenth century), or Alüksta. However, Kazimieras Būga attributes the name Alūksta to the seventh and eighth centuries (Būga RR II 108, III 535). The folk etymology links this toponym to the Latv. common word alksnājs 'alder forest' (the local dialect form oluksnājs), but there may be a scientific basis for regarding the claim as a possible hypothesis. (Lvv I 24, Dambe 1987: 39, Balode and Hirša 2009: 283, Balode and Bušs 2015: 54-55). 
Gulbene - a town in the north-east of Vidzeme (see map No 5), having received town privileges in 1928. This oikonym was first mentioned in German documents in 1224 as Gulbana; in 1340, a stone castle was built and referred to as Schwanenburg in German $<$ Germ. Schwan 'swan'. This town name is likely to have a purely Latvian origin, derived from the Latv. bird name gulbis 'swan' (cf. also Lith. guilbe 'idem'). (BHO II 566-567, Konv.VI 10977-10979, Lvv I 339, Balode and Bušs 2015: 108).

Some town names could be considered as names of Lithuanian origin - all located close to the Lithuanian border, such as the following examples:

Auce - a town in south-west Zemgale (see map No 6), near the River Auce. This name was first recorded in historical sources in 1426 as Owcze, later Autz and Alt-Autzen (BHO II 45). At the end of the nineteenth century, near the Auce railway station, Auce began to develop as a small town, obtaining town privileges in 1924 . The oikonym originated from the name of the River Auce, which flows out from Lake Lielauces ezers. Jānis Endzelīns writes that the River Auce is rapid in its upper reaches, and for this reason, it is possible to assume the link between the name and the Lithuanian verb išaukti (sic!) 'to cry out' (Lvv I 49) and probably the Latvian word auka 'gale'. Kazimieras Būga (Būga RR III 256) relates the toponym Auce to the Lithuanian common word auke without mentioning the meaning of this Lithuanian appellative. In addition, no such common word is included in the 20-volume Dictionary of Lithuanian (Lietuvių kalbos žodynas) (moreover, the Lith. verb išaukti, which was proposed by Endzelīns, could have the root šauk-, rather than auk-). Aleksandras Vanagas (LHEŽ 52-53) argues that the Lithuanian river name of Aũkupis and other Lithuanian hydronyms with the stem $A u k$ - are likely to be related to the Latvian Auce and could be coined from the Lithuanian verb aukúoti 'to swing, dandle'. This semantic motivation for the hydronym appears to be highly credible; and this certainty is further supported by the obvious semantic similarity to another Latvian place name - a town name as well as river name, Lìgatne < Latv. verb ligot, ligoties 'to sway, swing'. By contrast, Konstantīns Karulis (Karulis I 87) links the Latvian appellative auka 'strong storm' to words denoting noise, such as the Lithuanian dialect word áukterti 'to yowl'; verbs denoting sounds often serve as a basis for river names, and thus this type of link (Auce : auka) does not seem implausible. (Balode and Bušs 2015: 61-62) 
An even more credible Lithuanism is located on the Lithuanian border:

Subate - a town in Sēlija (see map No 7), on the banks of Lake Subates ezers. As early as the sixteenth century, a settlement began to develop on a merchants' route (name recorded in 1570). Subate obtained town privileges in 1917. The place name originated from the Lithuanian dialectal word subata - a Slavism meaning 'Saturday' Saturday was the biggest and most important day for trading. Incidentally, the names of the week (mainly the trading days) were used to coin a couple of place names in Lithuania: Pandelys $<$ the Lith. dialectal lexeme pãnedèlis 'Monday', Seredžius $<$ the Lith. dialectal seredà 'Wednesday' (Otrębski 1961: 56-57). Even so, Aleksandras Vanagas is inclined to regard the name of the Lithuanian town of Subačius as having an anthroponymic origin - to have originated from the surname Subačius rather than directly from the Lithuanian subatà 'Saturday' (Vanagas 2004: 199-200). (Balode and Bušs 2015: 228-229)

One possible Lithuanism (although with a question mark, due to its location far from the Lithuanian-speaking area) is the name of the Latvian town of Piltene (see map No. 8):

Piltene - an ancient inhabited place in the north of Kurzeme, by the old riverbed of the River Venta. The Piltene castle (Pilten) was first mentioned in 1309. Piltene has had town privileges since 1557. Jānis Endzelīns relates the name of the town to the Lithuanian verb pilti 'patter, pour', which corresponds to the Latvian dialectal verb pilt 'to dribble' that was recorded in Dundaga. Endzelinns suggests that the original meaning of the place name was 'manually raised (castle) mound' and compares it to several Latvian hill names - Piltina kalns, Piltinu kalns, as well as to some other similar place names. For comparison, one can also mention a Lithuanian common noun, piltine 'moulded hill'. (Biel. Gr. 196, Endzelīns DI III1 522, LVV 2006: 38, Balode and Bušs 2015: 175-176).

Several of the town names in Latvia are considered to be of Baltic/ Curonian origin, but they are very hypothetical. There are very few language features known of this ancient Baltic language, but based on the phonetics and lexicon, these names could be possible Curonianisms: Durbe, Grobina, Kuldīga < Kuldinga (?), Nìca, Priekule, Sabile, Stende, Talsi (?); for instance, more detailed analysis of the town name Sabile:

Sabile - a town in the north-east of Kurzeme (see map No. 9). A document published in 1253 records it as Zabel, it is recorded as Sabelen in 1438, and later in German as Zabeln (BHO II 721). Sabile 
has had town privileges since 1917. Jānis Endzelīns mentions this name among the place names that, in terms of their form, are considered to be of Curonian origin: according to Endzelins, the evidence for the Curonian origin is the (historical) suffix -il- (Endzelīns D III2 255-256). Valentin Kiparsky (Kiparsky 1939: 149) indicates that this suffix can also be found in Old Prussian place names (Endzelīns himself used the Prussian Tapilkayme for the comparison) and therefore it may be of unspecified Baltic origin; considering the modern perception of the Curonian language as - at least initially - a West Baltic language, the suffix -il- could perhaps be considered to be West Baltic, i.e. at least common for the Prussian and Curonian languages. The root of the name Sabile could be the same as the root in the Prussian place names Sabenowe, Saboniten, and the Prussian personal names Sabine, Sabune; the latter names are compared by Georg Gerullis to the Lithuanian personal names Sabas, Sabonis (Gerullis 1922: 147-148), whereas the analogical contemporary Lithuanian surnames are believed to have derived from a borrowed personal name, Sebastijonas (LPŽ II 652, 654), which is unlikely to be related to the name Sabile. Perhaps the oikonym is linked to the rare Latvian dialectal adjective from Zemgale, i.e. sabrs 'strong, stocky', the substantive sabris 'strong man' (ME III 597), if they are inherited names with the historical suffix $-r$ - However, no other Latvian common nouns or verbs are considered to be credible etymons for the toponym Sabile. (Balode and Bušs 2015: 196-197, Biel. Gr. 184-185).

\section{2b. Oikonyms of Finnic and Germanic origin}

Approximately ten contemporary towns/cities in Latvia could be regarded as having names of Finnic origin - some of them are more and some less credible: Ainaži, Ikšķile, Jelgava, Limbaži, Matkule, Rüjiena, Vangaži, Valka (?), Kuldīga (?), Viļaka (?). At least one such example of all these possible Finnicisms with greater reliability is Rüjiena (see map No 10):

Rüjiena - a town in the north of Vidzeme, ten kilometres from the Estonian border, has had town privileges since 1920. At the beginning of the fourteenth century, a stone castle in Rūjiena already existed (Germ. hove to Ruyen) and a village began to develop next to it. The inhabited place derived its name from the River Rüja, which runs through the city and flows from the Estonian Lake Ruhijärv (cf. the Estonian lexeme ruhi 'manger; log boat', see also EKR 2016: 565, 566). Kazimieras 
Būga (Būga RR III 508, 617) and Marta Rudzīte (Rudzīte 1968: 190) believe the river name of Rujja to be a word of Finnic origin and compare it to another Estonian lake name, Ruhja järv. Aleksandras Vanagas (LHEŽ 283) seems to agree, although he does not consider the Lithuanian hydronyms of the same root to be Finnicisms. Hypothetically, the name of Rüjiena could also be linked to the Latvian lexeme rüja 'rut' (ME III 568), but this relation seems less credible. (LVV 2013: 510, Balode and Bušs 2015: 194-195).

It is rather difficult to explore the town names of Germanic origin in Latvia because they all came into Latvian through the intermediation of German anthroponyms, for example:

Ape (a local pronunciation is Opa or Ope) (see map No 11) - a town in the north-east part of Latvia near the Estonian border, on the left bank of the River Vaidava. Ape developed from a former manor estate and obtained town privileges in 1928. This manor was called Hoppenhof or Hopfenhof in German (BHO II 224). The name was coined from the German surname Hoppe, which originally is linked to the contemporary German appellative Hopfen 'hops'. In 1421, the Master of the Livonian Order, Sigfried Lander von Spanheim, gave the manor to Gerhard Hoppe, and his descendants governed in the region for many years. (Lvv I 37, Balode and Hirša 2009: 283, Balode and Bušs 2015: 56-57).

In addition, as a possible indirect Germanism that came to Latvia through a personal name, one should mention examples of town names such as Brocēni and Lìvāni:

Brocēni (pronounced as Bruocēni, earlier Bruoceni) (see map No 12) - a town in the south-east of Kurzeme, five kilometres to the north-east of Saldus between Lake Brocènu ezers and Lake Cieceres ezers. Brocēni was granted urban village status in 1950, and town privileges in 1992. The name Brocēni was first mentioned in a document dating to 1528; at the beginning of the eighteenth century, it was recorded in two ways: Brautzen (1702), Brozen (1704), while the name of Lake Brocēnu ezers has been known since the sixteenth century as Protzeneekscher See (1574) (BHO II 91), which leads to the hypothesis that the settlement (possibly a manor) might have once been called *Brocenieki. Furthermore Vallija Dambe (Dambe 2012: 332) and other authors have highlighted that the form of the toponym with the short vowel $-e$ - in the auslaut of the word is historically more correct, i.e. Broceni. The basis for this might have been the German surname Brotze or variations of this surname, which in German may have derived as a hypocoristic form from the personal name Ambrosius. However, there is no historical evidence of a person (possibly a manor owner) bearing 
such a surname. For this reason, one should also consider the position of Dzintra Hirša (Hirša 2008: 24-26), who claims that the origin of the place name Brocenni might be linked to the Baltic languages, i.e. the Latv. verbs braukt 'go, drive', braucit 'rub, stroke', the Curonian verb braucēt ('go to the sea', cf. the place name's recording of 1702, i.e. Brautzen), as well as Latvian braukt, braucināt with the old meaning of 'scrub, rub; sharpen, hone'. Since Lake Cieceres ezers lies on limestone deposits, the place name Broceni might have been related to the name of a hand tool used to work limestone. Hirša proposes hypothetically reconstructing the word *brocis, which could also have the meaning 'person who handled limestone'. The aforementioned hypotheses would be more credible if the history of the town name had originated from the name of a farmstead. (Balode and Bušs 2015: 73-75)

An analogical example of a possible indirect Germanism is the next town name:

Liva anni (the local pronunciation is Leivuons; the local inhabitants use this name as a singular noun) - a town in the south-west of Latgale (see map No 13), on the right bank of the River Daugava, at the mouth of the River Dubna; it has had town privileges since 1926. In 1533, a settlement called Livenhof or Lievenhof in German was founded here by Jürgen Lieven, the vassal of the Archbishop of Riga, and the village was the property of the Lieven (also Liewen) family until 1574 . According to legend, the progenitor of the family was Nicholas, a grandson (daughter's son) of the Livonian chieftain Kaupo, and thus the family name would be linked to the ethnonym (German Liven, Latin Livones, i.e. the Livonians). (Konv. XII 23839, Latkovskis 1940: 134, Zeps 1984: 271, Balode and Bušs 2015: 152-153).

\section{2c. Obscure oikonyms}

However, many unclear and rather obscure oikonyms have two or even more explanations for their origins, as in the following example:

Ogre (pronounced as Uogre) - a town situated on the banks of one of the most rapid rivers in Latvia - Ogre - where it flows into the River Daugava. This settlement name was mentioned as early as in 1206 , and the town has had town privileges since 1928. One of the most credible hypotheses, which was formulated by Kazimieras Būga (Būga RR III 543), derives the river name Ogre from the reconstructed form *Vangrie , which is related to the Lith. adjective vingrùs 'meandering, curly', and the Latv. vingrs 'nimble, skilful'. In other words, the river 
name Ogre could mean 'the meandering river'. It seems that the Baltic and Slavonic common root *angra- 'similar to a snake', which was reconstructed by Vytautas Mažiulis (Mažiulis 1988, 79-80) and which is also indirectly linked to the Latvian place name Engure, belong to the same etymologic nest as Ogre. The Proto-Baltic and Lithuanian syllabic diphthong - an- corresponds to the Latvian diphthong -uo-, and this is why the correspondence between *angra- and Ogre is highly probable. However, another hypothesis of the etymology has been posited that links this hydronym to the Finnic languages: the Chronicle of Henry from the thirteenth century mentions the form of the river name as fluvius Wogene, which allows us to link it to Est. voo or voog, voogu 'stream', and Est. voogama 'to flow' (Karma 1994: 150-154); but perhaps these names - Wogene and Ogre - are etymologically unrelated. (Alvre 1985: 32-34, Balode 1980: 26, Balode and Hirša 2009: 292, Balode and Bušs 2015: 166-167).

Nonetheless, there is currently no clear origin of popular town names such as Cèsis, Cesvaine, Madona (the latter has only a folk-etymology, which connects this place name to the Latv. dialectal adjective moduons [=*muoduons?] 'early, brisk, vigilant, playful'; another folk explanation, which is considered to be a legend, relates it to the personal name Made (it is said that a woman bearing such a name drowned in the nearby Lake Madonas ezers) (Balode and Bušs 2015: 159-160). Moreover, the etymology of town names such as Ilükste, Kandava, Krāslava, Sigulda, and Stende are also uncertain, but some hypotheses are expressed in the aforementioned book "No Abavas līdz Zilupei" (2015).

\section{Hybrid names}

From the etymological viewpoint, some Latvian town names are coined as hybrid names-composites:

Mazsalaca (see map No 14) < Latv. adjective mazs 'small' + Finn. (?) Salaca - a river name that has several Finnic and Baltic explanations, including folk-etymologies as well (as the Latv. sala 'island' + acs 'eye'), but most probably it is a hydronym of Livonian origin: cf. the Liv. saletsa 'salty river' (but this lexeme is not recorded in Livonian dictionaries), or the Curonian Livonian lexeme salai 'biting, pungent' (see also EKR 2016: 588-589), with the following possible Baltic juxtapositions: the Lith. river name Salantas and the verb sálti 'to flow', and others. (Balode and Bušs 2015: 162-164); 
Salacgrīva (see map No 15) < Finn. (?) Salaca (see sub voce above Mazsalaca) + Latv. grīva 'estuary' (Balode and Bušs 2015: 198-199);

Jaunjelgava (see map No 16) - this town name has changed many times over the centuries. For instance, Jaunjelgava has been known as Sèrene, Jaunpilsēta, Jelgaviña, Jaunā Jelgava, Lubu Jelgava, and it was recorded as Neustadt and Friedrichstadt in German. The contemporary name is comprised of the Latv. adjective jauns 'new'+ Jelgava - the name of another city located rather far away, the former capital of the Duchy of Courland, which could be of Finnic origin, i.e. the Livonian common name jālgab 'city' (Endzelīns D III2 46-50), but numerous hypotheses are posited for the origin of this name - the Baltic etymon as well as the Finnic etymon (Balode and Bušs 2015: 113-114, 117-120).

\section{Motivation of oikonyms}

From the point of view of motivation, the names under review are predominately related to hydronyms: coined from the names of rivers (or potamonyms), less often - from the names of lakes (or limnonyms), such as Ainaži $<$ the river name (cf. the name of the border river of Haynejecke recorded in 1276), Aizkraukle < the river name Kraukle, Alüksne $<$ the lake name Alüksnes ezers, on whose southern bank it is located, and the river name Aluksne, Auce $<$ the river name Auce, Akniste $<$ the river name Akniste, Balvi $<$ the river name Bolupite and the lake name Balvu ezers, Daugavpils $<$ the river name Daugava, Ilükste $<$ the river name Ilūkste, Lìgatne $<$ the river name Ligatne, Lubāna $<$ the lake name Lubāns, Ludza $<$ the lake name Ludzas ezers and the river name Ludza, Mazsalaca $<$ the river name Salaca, Ogre $<$ the river name Ogre, Olaine $<$ the river name Olaine, Rēzekne $<$ the river name Rēzeknes upe, $\boldsymbol{R} \bar{\imath} g \boldsymbol{a}<$ Rìgas upe or Rìdzene, Rüjiena $<$ the river name Rüja, Salacgrivva $<$ the river name Salaca, Ventspils $<$ the river name Venta, Viesīte $<$ the river name Viesìte and the lake name Viesìtes ezers, Vilaka $<$ the lake name Vilsakas ezers, Zilupe $<$ the river name Zilupe (which appeared as a misunderstanding $<$ Sienupe $<$ Latv. siens 'hay' or Lith. siena 'border' + Latv. upe 'river').

Several town names are coined from personal names (or anthroponyms), although these are not as numerous as they are in other countries. Some of them are well-known historical persons, but some of them are rather obscure, for instance, Ape $<$ the German personal name, Gerhard Hoppe, who was the landlord of the estate, Brocēni $<$ (?) Germ. surname Brotze, Jēkabpils < Jēkabs - Duke of Courland 
Jacob who granted Magdeburg rights to the town, Lī $\bar{a} \bar{n} \boldsymbol{i} i$ Germ. Lieven, Liewen - the surname of the founder of the settlement, vassal of the Archbishop of Riga, Pāvilosta $<$ named after Paul von Lilienfeld brother of the founder of this port, Baron Otto von Lilienfeld, Staicele $<($ ?) the German surname Steitz, Stietzel, Staitzel, Strenči $<$ (?) the German surname Stren(t)z-, Stranz or the Latv. personal name Trencis, Valdemārpils $<$ Krišjjānis Valdemārs - an active member of the Latvian National Awakening, Valmiera < Valmiers or Valdimiers - maybe the name of the ruler of the old castle; actually it is difficult to explain which historical person the name was given after: there are two most popular versions - Prince Vladimir Mstislavich of Pskov or Valdemar II, King of Denmark.

\section{Some morphological features of the structure of oikonyms}

A brief insight into the formal derivation of the oikonyms under review attests to the fact that the names of the Latvian towns are predominately one-root toponyms (in spite of the popularity of composite names in other oikonyms, e.g. in homestead names): Baldone, Balvi, Bauska, Cēsis, Durbe, Ogre, Preiļi, Rìga, Saldus, Valka, etc. Suffix derivation is the most widespread type among derivatives. For example, the most popular suffixes are: -ava-Ārlava, Kandava, Kārsava, -āniLìvāni, Varakl̄āni, Viļāni, -ene - Gulbene, Piltene, Smiltene, and also Finnic-aži, which is still a rather obscure formant (see Biel. Gr. 45, 48, Endzelīns D III-2, 93, Balode 2015: 61-62) - Ainaži, Limbaži, Vangaži . The rarer suffixes (i.e. suffix + ending) that are used in coining Latvian town names are the following: -aine - Cesvaine, Olaine, -ona/-one Madona, Baldone, -āja - Liepāja, -ēni - Brocēni, -iņas - Pļavinas, -iena - Rüjiena. Only a few of the town names could be considered as prefixal derivatives. These are derived by using the prefix aiz- 'behind'Aizkraukle, Aizpute, one possibly with the prefix prie- 'near' - Priekule (?). Several of these oikonyms are clearly two-root names, such as the following composites: Daugav-pils, Jēkab-pils, Valdemār-pils, Ventspils (all coined with the second component the Latvian pils 'castle'), Jaun-jelgava, Jūr-mala, Maz-salaca, Salac-grìva, Pāvil-osta, Saulkrasti, and hypothetically also Als-unga (?), Liel-vārde (?).

The first impression of a derivational type is sometimes misleading. For instance, the contemporary oikonym Dobele, a town in the west of Zemgale on the bank of the River Bērze (see map No 17), appears to have been coined by using the suffix -ele from the well-known 
Latvian appellative duobe (or dobe in standard Latvian), which has the meaning 'pit; pothole; dip'. However, in a document of 1254, Dobele was recorded as Germ. Dubelene, Dubelone, and later as Doblene, Doblenen, and Doblen. These records testify to the fact that, inter alia, the original form of this place name was *Dobelene (or *Dobeliene, as reconstructed by Jānis Endzelīns) where -ene is the characteristic form of the settlement names of the Old Semigallians. The origin could be related to another Latv. word duobele 'small hollow; small pit; dip'; thus the reconstructed place name *Dobelene would most likely have meant 'a populated place in a small dip'. (EH I 349, ME I 531, Lvv I 246-247, Balode and Bušs 2015: 94-95)

Comparison of the grammatical number of the town names offers a somewhat surprising result. One could expect a priori that most of the Latvian oikonyms (homestead names and village names) would be pluralia tantum toponyms, but the proportion between singularia tantum and pluralia tantum in town/city names is $62: 14$. The following are a complete list of the pluralia tantum names in Latvia: Ainaži, Limbaži, Vangaži, Baloži, Balvi, Brocēni, Cēsis, Lìvāni, Preiļi, Pļaviņas, Saulkrasti, Strenči, Talsi. All of them, with the exception of two-Césis and Plavinas - are names that have masculine gender.

To compare the gender of town-names, the majority of these names have feminine gender (perhaps the gender of geographical nomenclature words have also influenced the gender of oikonyms, cf. Latv. vieta 'place', pils 'castle', pilsêta 'town, city' - all these appellatives in Latvian are words bearing feminine gender). The oikonyms that take masculine gender are only the following fourteen town names (almost all them pluralia tantum names): Ainaži, Limbaži, Vangaži, Baloži, Balvi, Brocēni, Lìvāni, Preilili, Saulkrasti, Strenči, Talsi, as well as Saldus and Kegums (the latter two are singularia tantum names).

\section{Summary}

As demonstrated, rather many names of towns/cities in contemporary Latvia are of Baltic origin (Latvian, Curonian, Lithuanian), some are borrowings from Finnic - in the Northern part of the country, and there are very few Germanisms - predominantly indirect Germanisms, i.e. coined from the anthroponyms of German origin; three town names - possibly hybrid composites. Many toponyms under review have several hypotheses concerning their origin. Each Latvian town or city name is worthy of a separate analysis - even a separate article 
could be devoted to hypothetical oikonyms. They all are (or will all soon be) included in the Dictionary of Latvian Place Names - "Latvijas PSR vietvārdi" and "Latvijas vietvārdu vārdnīca" (Lvv I, II, LVV 2003, 2006, 2010, 2013), which was initiated by Jānis Endzelīns and is still a work in progress by the toponymists at the Latvian Language Institute (University of Latvia).

\author{
Address: \\ Laimute Balode \\ University of Helsinki \\ Department of Modern Languages \\ Unioninkatu $40 \mathrm{~B}$ \\ FI-00014 Helsinki, Finland \\ E-mail: laimute.balode@helsinki.fi \\ University of Latvia \\ Latvian Language Institute \\ Akadēmijas laukums 1 \\ LV-1050 Rīga, Latvija \\ E-mail: laimute.balode@lu.lv
}

\begin{abstract}
Abbreviations
Est. - Estonian, Germ. - German, Latv. - Latvian, Lith. - Lithuanian, Liv. - Livonian
\end{abstract}

\title{
References
}

Alvre, Paul (1985) "Eesti ja liivi keeleaines Henriku Liivimaa kroonikas III". Keel ja Kirjandus 1, 32-36.

Balode, Laimute (1980) “Aiviekste. Ogre”. Draugs 1, 26.

Balode, Laimute (1994) "Dauguvos intakų hidroniminè analizė potamonimų stratifikacijos aspektu". Baltistica XXIX (2), 207-214.

Balode, Laimute (2015) "Criteria for identifying possible Finnicisms in Latvian toponymy”. In Santeri Junttila, ed. Uralica Helsingiensia. Contacts between the Baltic and Finnic languages, 49-73. (Uralica Helsingiensia 7.) Helsinki: Suomalais-Ugrilainen Seura.

Balode, Laimute and Ojārs Bušs (2015) No Abavas līdz Zilupei. Vietvārdu cilmes ìsā vārdnīca. From Abava to Zilupe. The origin of Latvian geographical names. A short dictionary. Rīga: Latviešu valodas aǵentūra. 
Balode, Laimute and Dzintra Hirša (2009) "On several names of Latvian inhabited places”. Balto-slavjanskie issledovanija: sbornik nauchnyx trudov 18. Moskva: Jazyki slavjanskix kul'tur, 279-299.

BHO II = Feldmann, Hans und Heinz von zur Mühlen, eds. (1990) Baltisches historisches Ortslexikon. Teil II: Lettland (Südlivland und Kurland). Köln, Wien: Böhlau Verlag.

Biel. Gr. = Bielenstein, August (1892) Die Grenzen des lettischen Volksstammes und der lettischen Sprache in der Gegenwart und im 13. Jahrhundert. St. Petersburg.

Būga RR I, II, III = Būga, Kazimieras (1958-1961) Rinktiniai Raštai I-III. Vilnius: Valstybinè politinès ir mokslinès literatūros leidykla.

Dambe, Vallija (1987) "Ieskats Latvijas PSR hidronīmu semantikā". Onomastikas apcerējumi. Rīga: Zinātne, 32-47.

Dambe, Vallija and Teodors Zeids (1980) "Vēlreiz par Rīgu". Zvaigzne 6, 8.

Dambe, Vallija (1990) "Par Rīgas vārda izcelsmi”. Onomastica Lettica. Rīga: Zinātne, $5-20$.

Dambe, Vallija (2012) Darbu izlase. Rīga: LU Latviešu valodas institūts.

EH = Endzelīns, Jānis and Edīte Hauzenberga. Papildinājumi un labojumi K. Mīlenbaha "Latviešu valodas vārdnīcai” I-II, Rīga, 1934-1946.

EKR 2016 = Eesti kohanimeraamat. Marja Kallasmaa (koostaja), Evar Saar, Peeter Päll, Marje Joalaid, Arved Kiristaja, Enn Ernist, Mariko Faster, Fred Puss, Tiina Laansalu, Marit Alas, Valdek Pall, Marianne Blomqvist, Marge Kuslap, Anželika Šteingolde, Karl Pajusalu ja Urmas Sutrop. Tallinn: Eesti Keele Sihtasutus.

Endzelīns D I-IV = Endzelīns, Jānis. Darbu Izlase I-IV. Rīga: Zinātne, 1971-1982.

Gerullis, Georg (1922) Die altpreussischen Ortsnamen. Berlin und Leipzig: Vereinigung Wissenschaftlicher Verleger.

Hirša, Dzintra (2008) "Par dažiem Latvijas pilsētu nosaukumiem I (Bauska un Brocēni)". In No skaņas un burta lìdz tekstam un korpusam. Sinhronija un diahronija. Akadēmiķa Jāņa Endzelīna 135. Dzimšanas dienas atceres starptautiskās zinātniskās konferences materiāli. Rīga: LU Latviešu valodas institūts, 21-27.

Karma, Tenu (1994) "Septinini lībiski vietvārdi Daugavas krastos”. In Daugavas raksti. No Rīgas lìdz jūrai. Rīga: Zinātne, 150-154.

Karulis I, II = Karulis, Konstantīns (1992) Latviešu etimologijas vārdnīca I-II, Rīga: Avots.

Kiparsky, Valentin (1939) Die Kurenfrage. Helsinki: Suomalainen Tiedeakatemia.

Konv. = Latviešu konversācijas vārdnīca I-XXI. Rīga: Grāmatu apgādniecība A. Gulbis. 1927-1940.

Latkovskis, Leonards (1940) "Līvānu izloksne". Filologu Biedrības Raksti XX. Rīga, $134-158$.

LHEŽ = Vanagas, Aleksandras (1981) Lietuviu hidronimu etimologinis žodynas. Vilnius: Mokslas.

LPŽ I, II = Lietuviu pavardžiu žodynas I, II. Ats. red. A. Vanagas. Vilnius: Mokslas, 1985, 1989.

Lvv I, II = Endzelīns, Jānis. Latvijas PSR vietvārdi I d. 1.sēj. (A-J) and I d. 2. sēj. $(K-\bar{O})$. Rīga: Latvijas PSR Zinātṇu akadēmijas izdevniecība, 1956, 1961. 
LVV 2003 = Latvijas vietvārdu vārdnīca. Paaglis - Piķu-. Ed. by Ojārs Bušs. Rīga, Latviešu valodas institūts.

LVV 2006 = Latvijas vietvārdu vārdnīca, Pilaci-Pracapole. Ed. by Ojārs Bušs. Rīga:

LU Latviešu valodas institūts.

LVV 2010 = Latvijas vietvārdu vārdnīca. Pracirika - Puožu. Ed. by Ojārs Bušs. Rīga, Latviešu valodas institūts.

LVV 2013 = Latvijas vietvārdu vārdnīca, $R$. Ed. by Ojārs Bušs. Rīga: LU Latviešu valodas institūts.

Mažiulis, Vytautas (1988) Prūsu kalbos etimologijos žodynas I. Vilnius: Mokslas.

ME = Mülenbachs, Kārlis. Latviešu valodas vārdnīca I-IV. Rediǵējis, papildinājis, turpinājis J. Endzelīns. Rīga: Kultūras fonds, 1923-1932.

Otrębski, Jan (1961) "O badaniach nad nazwami wodnymi i miejscowymi na obszarze Litwy”. In I Międzynarodowa slawistyczna konferencja onomastyczna, WrocławWarszawa-Kraków, 49-58.

Rudzìte, Marta (1968) "Somugriskie hidronīmi Latvijas PSR teritorijā". In Latviešu leksikas attīstība. Rīga: Zinātne, 175-197.

Vanagas, Aleksandras (2004) Lietuvos miestu vardai. Vilnius: Mokslo ir enciklopedijų leidybos institutas.

Zeps, Valdis Juris (1984) The placenames of Latgola. A dictionary of East Latvian toponyms. Madison, Wisconsin: Baltic Studies Center.

Data of PMLP = Latvijas iedzīvotāju skaits pašvaldībās pagastu dalījumā (PDF). Iedzīvotāju regíistra statistika uz 01.01.2016. Pilsonības un migrācijas lietu pārvalde. 2016. gada 1. janvārī. [Statistics of the population on 01/01/2016. The Office of Citizenship and Migration Affairs. Data on 1 January 2016]. Available online at $<\mathrm{http}$ :// www.pmlp.gov.lv/lv/assets/documents/Iedzivotaju\%20registrs/0107iedzregj/ ISPV_Pasvaldibas_iedzivotaju_skaits_pagasti.pdf $>$. Accessed on November, 2016.

Maps are design by Edmunds Trumpa.

Kokkuvõte. Laimute Balode: Pilk Läti linnanimedele. Kohanimede päritolu on keeleteadlaste (täpsemalt nimeuurijate) ja geograafide uurimisvaldkond, mis on ammustest aegadest huvi pakkunud ka kõikidele teistele. Kuna Läti on Leedu ja Eesti lähinaaber, jagavad riigid suurel määral ühist ajalugu, mistõttu on neil ka hulk ühiseid laensõnu ja laenatud nimesid. Käesolev artikkel põhineb Läti kohanimeleksikoni "No Abavas līdz Zilupei” toponüümilisel ainestikul. See heidab pilgu tänapäeva Läti oikonüümide olukorrale ning võrdleb asustuste nimesid nende ajalooliste nimedega.

Märksõnad: onomastika, linnanimed, Läti 


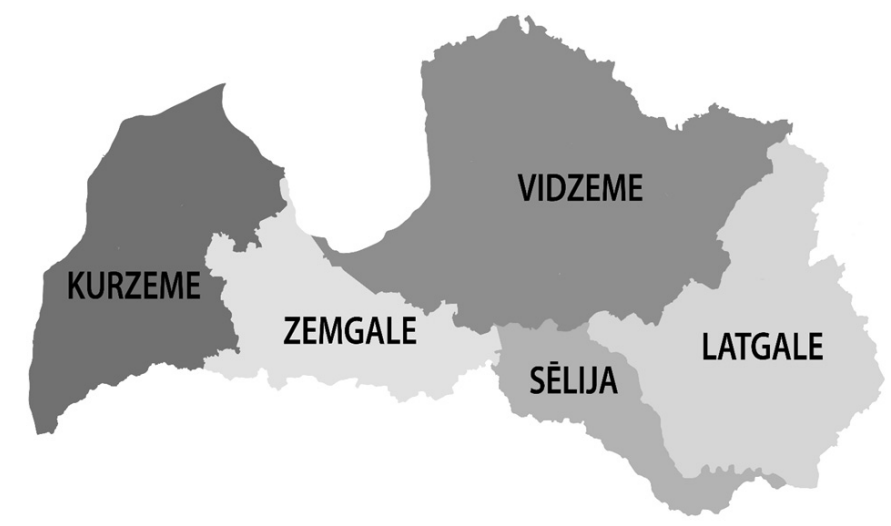

Map No 1. Cultural ethnographic regions of Latvia

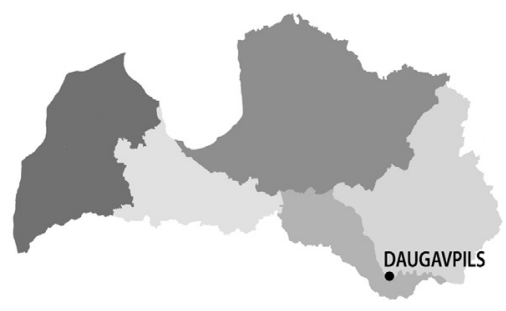

Map No 2

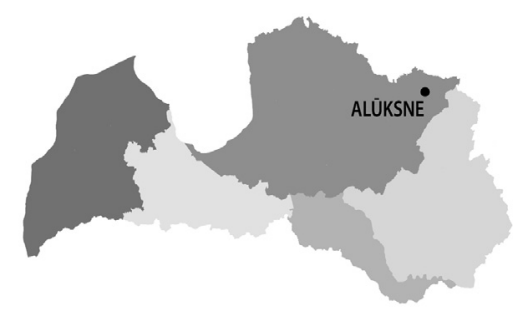

Map No 4

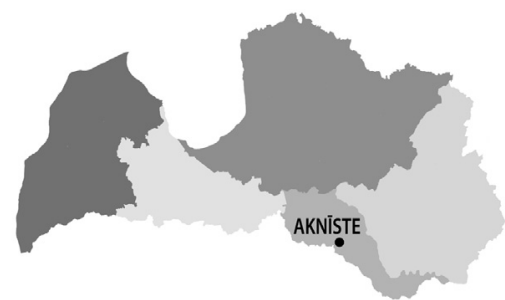

Map No 3

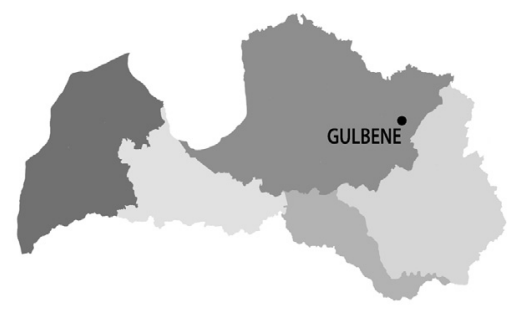

Map No 5 


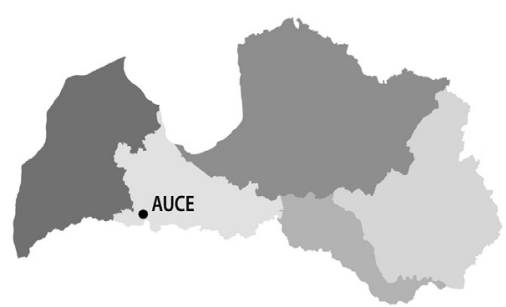

Map No 6

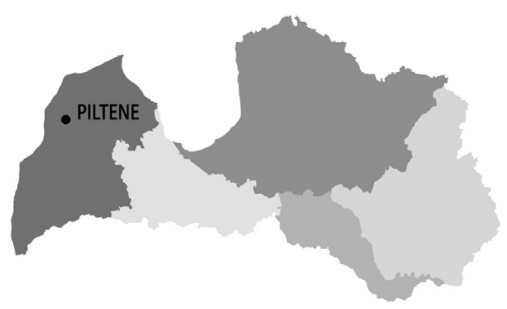

Map No 8

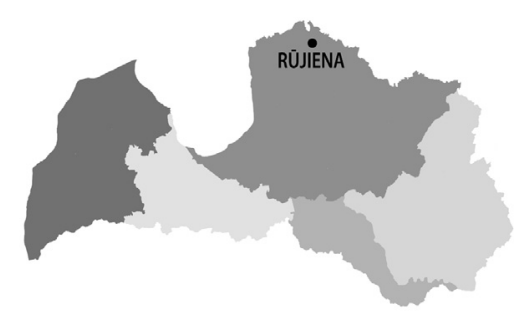

Map No 10

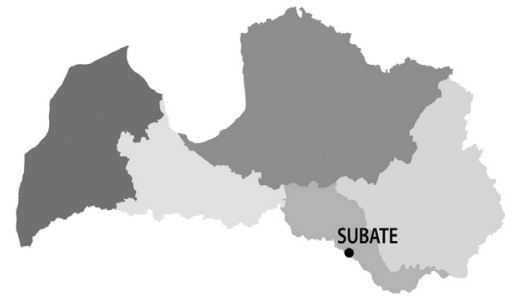

Map No 7

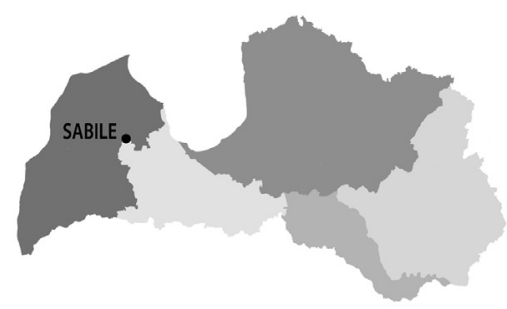

Map No 9

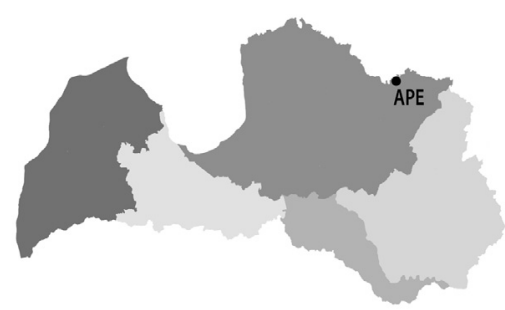

Map No 11 


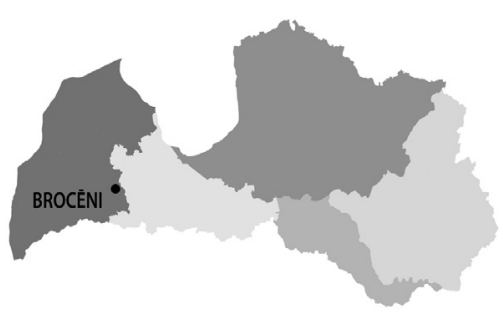

Map No 12

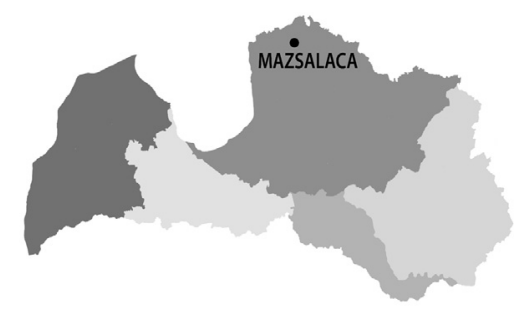

Map No 14

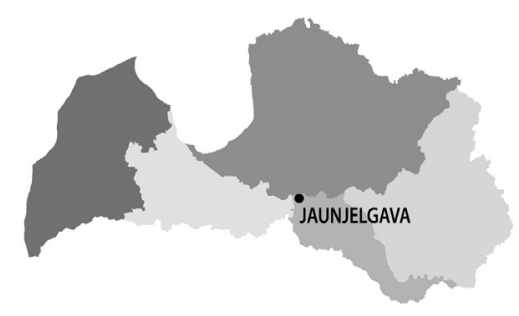

Map No 16

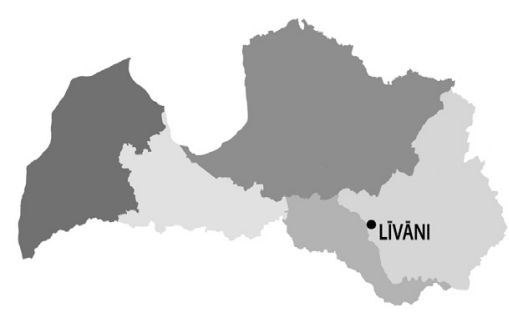

Map No 13

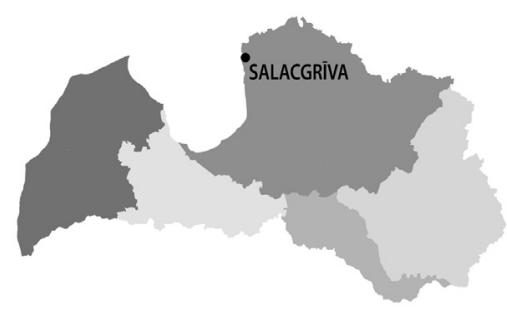

Map No 15

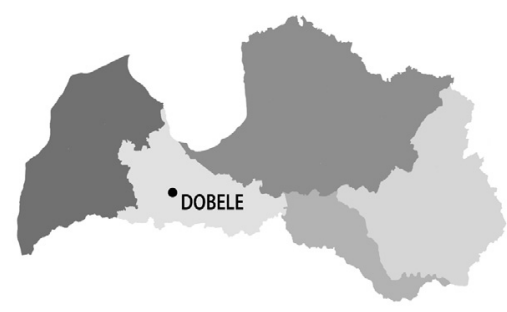

Map No 17 